NBER WORKING PAPER SERIES

\title{
FEDERAL DEFICIT POLICY AND THE EFFECTS \\ OF PUBLIC DEBT SHOCKS
}

Robert J. Barro

Working Paper No. 443

\author{
NATIONAL BUREAU OF ECONOMIC RESEARCH \\ 1050 Massachusetts Avenue \\ Cambridge MA 02138 \\ February 1980
}

Prepared for the Seminar on Rational Expectations, February 1, 1980, at the American Enterprise Institute for Public Policy Research. The research underlying this paper is supported by the National Science Foundation. The research reported here is part of the NBER's research program in Economic Fluctuations. Any opinions expressed are those of the author and not those of the National Bureau of Economic Research. 
Federal Deficit Polfcy and the Effects of Public Shocks

\author{
ABSTRACT
}

Shifts between current taxation and debt issue alter the timing of taxes, which induces a variety of intertemporal substitution effects. In some circumstances the minimization of excess budget costs would entail stabilization of expected overall tax rates over time. The first section of the paper discusses this condition and derives its implications for the behavior of public debt. Empirically the major movements in U.S. public debt can be explained along the lines of the theoretical model as sensible responses to business fluctuations, changes in government expenditures, and variations in the anticipated inflation rate. In particular, much of federal deficit policy appears to be consistent with economic efficiency. The next section focuses on the economic effects of debt shocks, which are interpreted as departures of public debt movements from the systematic behavior that was investigated in the previous section. It is possible theoretically that these shocks could influence aggregate demand even when such effects did not arise from the systematic behavior of the deficit. The constructed debt shocks appear to have expansionary influences on output and negative effects on the unemployment rate, although the magnitudes of the effects that have been isolated are substantially weaker than those estimated for money shocks. Because it is the shock component of deficits rather than the systematic "policy" response - that has been shown to affect real economic activity, the results do not provide a basis for using the deficit as an element of activist stabilization policy. Overall, the results do not suggest much payoff from the imposition of restrictions on federal deficit behavior; it is likely that such constraints would mainly increase the excess burden that is imposed on the private sector by fidnaneing of government expendit tures.

Robert J. Barro Department of Economics University of Rochester Rochester, New York 14627 
Federal Deficit Policy and the Effects of Public Debt Shocks

$$
\text { Robert J. Barro }
$$

The University of Rochester

and

National Bureau of Economic Research

January 1980

*Prepared for the Seminar on Rational Expectations, Feburary 1, 1980, at the American Enterprise Institute for Public Policy Research. The research underlying this paper is supported by the National Science Foundation. 
It is standard practice in macroeconomics to focus on the aggregate demand and stabilization policy aspects of federal deficits. The usual macroanalysis neglects the implications of the choice between current taxation and the issue of interest-bearing debt for the time pattern of tax collections. If the aggregate demand effects of the debt/tax choice are not the dominant considerations--as in the Ricardian equivalence case discussed but not necessarily supported in Ricardo (1951, pp. 184-89), Buchanan (1958, pp. 43-46, 114-22), Bailey (1971, pp. 156-58), Barro (1974) and Buiter and Tobin (1978), et.al.--then an assessment of the substitution effects associated with the timing of taxes may be a key element in positive and normative analyses of public debt behavior. These types of allocative effects would most naturally be studied from the viewpoint of public finance theory, which is the perspective that I employ in the present paper. The spirit of the approach is to go as far as possible theoretically and empirically in analyzing deficit policy as the choice of tax rates over time in a setting where the usual first-order macroeconomic effects are not present, but where allocative issues arise that involve intertemporal substitution effects produced by changes in the timing of taxes.

The first section summarizes some theoretical arguments on the debt/tax choice that were presented in an earlier paper of mine (1979). The propositions that are derived for public debt behavior center around a condition of maintaining constant expected overall tax rates over time. Empirical evidence is then reviewed on the long-term behavior of public debt in the United States. The basic conclusion is that the major movements in public debt can be explained along the lines of the theoretical model as sensible responses to business fluctuations, changes in government expenditures, and variations in the anticipated inflation rate. In particular, the public 
finance perspective suggests that much of federal deficit policy has been consistent with economic efficiency. The next section focuses on the economic effects of debt shocks, which are interpreted as departures of public debt movements from the systematic behavior that was investigated in the previous section. It is possible theoretically that these shocks could influence aggregate demand even when such effects did not arise from the systematic behavior of the deficit. The constructed debt shocks appear to have expansionary influences on output and negative effects on the unemployment rate, although the magnitudes of the effects that have been isolated are substantially weaker that those estimated for monetary shocks. Because it is the shock component of deficits--rather than the systematic "policy" response-that has been shown to affect real economic activity, the results do not provide a basis for using the deficit as an element of activist stabilization policy. Overall, the results do not suggest much payoff from the imposition of restrictions on federal deficit behavior; it is likely that such constraints would mainly increase the excess burden that is imposed on the private sector by the financing of government expenditures. 
Theoretical Considerations on Deficits and the Timing of Taxes

It is assumed that tax collection entails not only the transfer of resources from the private sector to the government, but also excess burdens that involve the distortion of allocative decisions, which include the time misallocated to tax computations and to the design of tax-avoidance schemes and any administrative costs incurred by the tax-raising institution. In other words "lump-sum" taxation is ruled out. If the present value of government expenditures is fixed, there will be a given present value of tax revenues to be raised. ${ }^{1}$ However, the fixity of this total leaves open the timing of tax levies. Generally, alterations in this timing, which are brought about by shifts between taxes and debt issue, will influence the overall amount of excess burden costs.

For present purposes I consider the behavior of a large national government, which can reasonably neglect the effects of the timing of taxes and public services on mobility in and out of its jurisdiction. (See Benjamin and Kochin, 1978, for a discussion of this matter.) In this circumstance the choice of tax rates over time to minimize the overall excess burden costs-that is, to minimize the deadweight resource loss from raising a given present value of net revenues--provides a criterion for optimal policy. For the present analysis I do not distinguish average from marginal tax rates; essentially, the relation between these rates is assumed to be fixed by the cross-sectional structure of taxation at a point in time, which is taken as given.

Suppose that taxes are levied on labor earnings or other activities at various dates. The existence of these taxes induces a variety of taxavoiding responses, including substitutions away from market work and toward 
non-market activities at various points in time. However, if the tax rates are equal over time, there are no tax-induced substitution effects on the intertemporal arrangement of work or other activities. If the sensitivity of supply to after-tax real returns is similar at different dates--in particular, if there is no strong interaction between supply elasticities and the contemporaneous levels of either government purchases or real wages-then a departure from this uniform pattern of taxation would generate extra deadweight losses. That is, in accordance with the usual "triangle" analysis in consumer surplus calculations, the loss from reduced effort at a high tax rate date would more than offset the gain associated with increased supply at low tax rate dates. As seems clear from the time symmetry of this model, optimal policy in this circumstance involves a uniform pattern of tax rates over time. Further discussion of this proposition appears in Barro (1979, pp. 941-45) and Kydland and Prescott (1980, ).

In an environment where future government spending and gross national product are uncertain, the precise constancy of tax rates over time would be unattainable, but optimal policy would seem to dictate an equality between current tax rates and anticipated future rates. (The model with uncertainty has not been worked out rigorously.) In this case unexpected shifts in the long-run average share of government spending in gross national product would induce corresponding changes in current and expected future tax rates. The current overall tax rate would be set so that--given the initial stock of public debt, the anticipated pattern of future GNP and government spending aside from interest payments, and the constraint imposed intertemporally by the government's budget--it would be impossible to predict future changes in 
overall tax rates. As with some price variables in efficient market models, tax rates would be generated from a random walk process.

Although constancy of expected tax rates over time would not be optimal in general, this condition may provide an approximate guide for desirable deficit policy--and thereby also a positive theory of behavior--under many circumstances. In any case it seems worthwhile first, to examine the theoretical implications of the constant expected tax rate policy and second, to explore the conformity of empirical evidence with these propositions. The stabilization of anticipated tax rates over time has a large number of implications for public debt behavior, some of which are familiar from alternative perspectives and some of which are new. These implications include the following:

1) Temporarily large government expenditures, such as war spending, extensive capital projects and international reparations payments, would be financed principally by debt issue. Major increases in current tax rates would be inconsistent with the expectation of reduced government spending in future periods. Current and expected future tax rates would be raised only to the extent of changes in the present value of expected government spending; that is, only in accordance with shifts in the "permanent" expenditure flow. Therefore, blips in expenditure that were anticipated at earlier dates would not be associated with changes in current tax rates. Further, in order to offset ex ante the positive effect on debt of infrequent, large wars, the debt-income ratio would decline, rather than remain constant, during typical peacetime years.

2) Expansions of government's share of gross national product that are perceived as permanent would be met by corresponding increases in current 
and expected future tax rates. This behavior is in line with the matching of taxes to permanent government spending.

3) If real government expenditures exhibit little cyclical variability, a tax-smoothing policy entails deficit finance during recessions and surpluses during booms. In this respect the behavior of government resembles that of individuals, who would tend to dissave during (temporary) bad times and save a large fraction of windfalls. In the basic model the amount of countercyclical deficit finance would be sufficient to stabilize overall tax rates over the business cycle; see below for a discussion of some conflicting empirical evidence.

4) The policy of maintaining stable tax rates over time is independent of the initial stock of outstanding public debt. Therefore, exogenous changes in the real debt stock would alter the overall level of tax rates (corresponding to the decline in long-run real interest payments), but would leave unchanged the growth rate of the debt, which determines the relative values of tax rates over time. In particular, the inverse effect of unanticipated inflation on the real value of dollar-denominated debt leaves unchanged the subsequent growth rate of the debt. ${ }^{2}$

5) An unanticipated increment in unfunded future liabilities, such as planned social security benefits, raises the long-run real government spending flow and therefore current taxes by the product of the real interest rate and the real present value of the future liability. There is a corresponding shift toward a surplus position in the current government budget, as defined to exclude the unfunded liabilities. That is, if other components of anticipated government spending are held fixed and no parts of the unfunded 
liability are paid off currently, the funded debt would decline in the present period by the product of the real interest rate and the change in the capitalized value of the unfunded debt. This behavior implies that movements in funded debt exactly offset predictable changes in unfunded debt. (I have not yet attempted to test this proposition empirically.)

6) Anticipated (exogenous) inflation has a one-to-one effect on the growth rate of nominal debt. A divergence between the debt growth rate and the expected inflation rate implies systematic movements in the stock of real debt and hence in real interest payments, which would be inconsistent with the policy of smoothing tax rates over time. Viewed another way, an increase in the anticipated inflation rate would tend to be associated with a corresponding increase in nominal interest rates ${ }^{3}$ and hence--neglecting the distinction between 10 g-term and short-term debt ${ }^{4}-$-with a rise in current real interest payments. The theory implies that these higher real interest payments are met with debt issue rather than increased taxes. This response maintains the previous pattern of anticipated values over time for taxes and the real stock of debt.

7) Anticipated growth in real income has a one-to-one effect on the growth rate of real debt. Any divergence here would produce systematic movements in interest payments relative to national income, which conflicts with the policy of maintaining stable tax rates over time. 
Empirical Evidence on Public Debt Behavior

In some earlier papers (Barro, 1979; 1978a) I have examined the conformity of some of the above propositions with the United States experience since 1916 on funded, privately-held, interest-bearing public debt. ${ }^{5}$ I have also looked less formally at the behavior of U.S. public debt over a longer period.

The first observation is that the principal peaks in the ratio of public debt to gross national product in the United States are associated with major wars; notably, with the Civil War, World War I and World War II. Each peak is followed by a steady decline in the debt-GNP ratio during the subsequent peactime periods: from a peak of .24 in 1865 to a trough of .018 in 1916, from .30 in 1919 to .14 in 1929, and from 1.07 in 1945 to .24 in 1978.

The analysis in Barro (1979, pp. 160, ff.) includes a detailed study of the response of federal deficits to shifts in federal spending, which picks up also the effects of smaller wars like Korea and Vietnam and includes other movements in federal expenditures. These findings are basically in accord with the theoretical objective of funding temporary spending increases primarily with debt issue in order to stabilize anticipated overall tax rates over time. Some details of this analysis are reproduced in the next section of this paper.

A second inference from the data is the important countercyclical response of the federal deficit to business fluctuations. Earlier discussions of this type of relationship include Committee for Economic Development (1947), Brown (1956), Council of Economic Advisers (1962, pp. 78-82), and Okun and Teeters (1970). A dramatic countercyclical reaction of this type appears 
during the Great Depression of the 1930s. Structurally similar behavior can account also for much of the well-publicized increase in federal debt during the 1974-76 recession. The detailed analysis suggests a stronger countercyclical response of the federal deficit than would be necessary to stabilize federal tax rates; that is, average federal tax rates seem to decline during recessions and rise in booms. (See equation (1) in the next section for some detailed estimates.) This behavior accords with estimates of the built-in flexibility of the federal individual income tax that are given in Pechman (1973). A number of suggestions, including attempts at activist stabilization policy, countercyclical behavior of factor supply elasticities, and the progressivity of the income tax $1 \mathrm{aw},{ }^{6}$ have been offered to explain the "excessive" countercyclical response of federal debt. An interesting possibility involves the federal government's interaction with state and local governments. Because of cross-jurisdiction mobility potential, Benjamin and Kochin (1978) argue that local governments would be in a less advantageous position than a large national government to pursue tax rate smoothing policies over the business cycle. (This difficulty may even be institutionalized in constitutional restrictions to balanced current account budgets at the state and local level.) An optimizing response of the federal government, which took account of the welfare of the citizens of each locality, would be a countercyclical response of the deficit that stabilized total government tax rates. Therefore, the countercyclical movement of the deficit would appear excessive--with a magnitude that depends on the ratio of total to federal government expenditures and on the cyclical behavior of state and local spending--when the federal government was viewed in isolation. The magnitude of this effect seems sufficient to reconcile the observed federal deficit behavior since the 1930 s 
with the objective of stabilizing total government tax rates over the business cycle, but this explanation may be difficult to sustain for the peacetime years before the 1930s, where state and local spending is typically two to three times the size of federal spending.

In any event the strong response of federal deficits to economic contraction is not a creation of the post-World War II period, but characterizes also the behavior in the 1930s. The same relationship is consistent with the smaller amount of evidence afforded by data from the less volatile period of the 1920s and, less formally, with observations from the pre-World War I period. Overall, there is no indication of growth over time in the extent of countercyclical deficit response.

Another finding from the data is a one-to-one link from anticipated inflation to the growth rate of nominal debt (Barro, 1979, p. 961). ${ }^{7}$ of course, this association does not settle the question of the direction of causation between debt issue and inflation. Some studies of post-World War II United States inflation (Gordon, 1975, p. 647; Barro, 1978b, p. 563) indicate that price level changes can be explained largely on the basis of monetary movements, although some puzzlingly long lags appear in these relationships. Even if correct, these findings leave open the possibility of a strong interplay between the deficit and money creation. ${ }^{8}$ However, some investigations of money supply determination (Barro, 1978a, pp. 576-78; Niskanen, 1978, pp. 597-602; Hamburger and Zwick, 1979) do not indicate an important role for the deficit, especially when the behavior of real federal spending relative to "normal" is held fixed separately. 9 Overall, it seems a reasonable preliminary inference that the inflation/deficit relationship is principally in the direction from anticipated inflation to nominal public debt 
movements, rather than the reverse.

The inflation influence appears to be a major determinant of nominal debt issue since the late 1960s. For example, at the end-of-1977 value of about $\$ 460$ billion for privately-held, interest-bearing public debt, roughly $\$ 30$ billion of the measured federal deficit for 1978 would have been required merely to maintain the anticipated real value of the outstanding debt. An inflationproof accounting system would delete this amount from the measured deficit; ${ }^{10}$ such an adjustment would be automatic (for actual rather than anticipated inflation) if the debt were issued in indexed form--assuming that the inflation correction to the outstanding nominal principal were not then included as part of the deficit. For example, the increase during 1978 by $\$ 44$ billion in privately-held, interest-bearing public debt should be rated as no more than $\$ 10-15$ billion of effective federal deficit.

Two other empirical findings that accord with the underlying theory are a lack of relationship between either the beginning-of-period public debtGNP ratio or the "lo1.g-run" federal expenditure-GNP ratio and the subsequent behavior of federal deficits (Barro, 1979, p. 966). 
Effects of Debt Shocks on Economic Activity

The above analysis suggests that a substantial fraction of public debt movements can be explained as responses to variations in business cycle variables, government expenditures, and anticipated inflation. Further, the bulk of these systematic responses can be rationalized from the objective of stabilizing anticipated overall tax rates over time. A different issue concerns the implications of federal deficit behavior for economic activity. This issue can be separated into two parts: first, what are the implications of the systematic behavior of the deficit; specifically, of the choice of parameters in a policy rule that relates public debt movements to the variables discussed above; and second, what are the effects of debt shocks; that is, of departures of public debt movements from the typical pattern? As has become clear from previous attempts to test natural rate hypotheses (Lucas, 1972; 1976; Sargent, 1976a, 1976b; Barro, 1980b, section V), it is at least difficult empirically to distinguish systematic movements from shocks and, thereby, to distinguish the two types of effects listed above. The central problem concerns the possibility of identifying the effects of changes in the parameters of a policy rule (in this case for public debt movements) from a sample where shifts in the policy regime have not been isolated. Such identification requires some additional a priori restrictions; for example, the omission of some variables that help to predict the deficit from other equations of interest, such as those for output and the unemployment rate. The analysis below includes some preliminary estimates for the effects of constructed "public debt shocks" on output and the unemployment rate. Because of the identification problems alluded to above, it is difficult to 
draw firm inferences from these results for some interesting policy questions. Reduced form analyses of business fluctuations, as in Barro (1980a), show major effects on output and the unemployment rate of monetary "surprises" and of movements in government purchases. Shifts in public debt, with the behavior of money and government purchases held fixed, have not yet been demonstrated to have these types of business cycle effects. One difficulty with reduced form empirical analyses of public debt effects is the endogenous, countercyclical response of the deficit, which tends to produce a negative reduced form correlation between output and public debt movements. ( $\rho f$ course, related problems arise in isolating monetary effects.) The full employment deficit concept was originated, in part, to filter out this endogenous response mechanism; see Brown (1956), Council of Economic Advisers (1962, pp. 78-82), and Okun and Teeters (1970) for discussions. This approach can be carried further to isolate debt shocks, which measure the departure of public debt movements from the amount associated normally with a set of explanatory variables. The discussion above indicates that important determinants of the federal deficit include current values of business cycle variables, government spending, and the anticipated inflation rate. The construction of debt shocks requires a detailed statistical relationship between the growth rate of public debt and the set of explanatory variables. For this purpose I utilize the regression equations that were estimated in my earlier public debt study. The estimated equation for the growth rate of the public debt, using annual data over the 1948-76 period, is (Barro, 1979, p. 961)

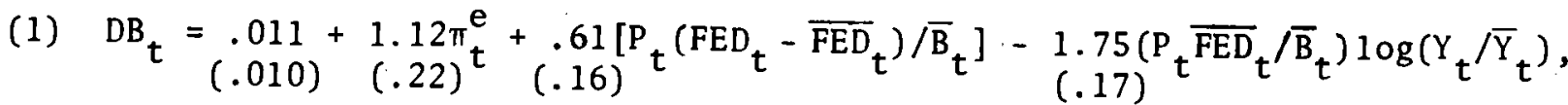

$$
\begin{aligned}
& \mathrm{R}^{2}=.87, \hat{\sigma}=.022, \mathrm{D}-\mathrm{W}=1.8,
\end{aligned}
$$


where standard errors are shown in parentheses, $\hat{\sigma}$ is the standard-error-ofestimate, and D-W is the Durbin-Watson Statistic. The variables contained in equation (1)--discussed in detail in the earlier paper--àre

$$
\mathrm{DB}_{t} \equiv \log \left(\mathrm{B}_{t} / \mathrm{B}_{\mathrm{t}-1}\right) \text {, where } \mathrm{B}_{t} \text { is the end-of-year stock of par value, }
$$
interest-bearing public debt, excluding holdings of the Federal Reserve and federal agencies and trust funds,

$$
\begin{aligned}
& \bar{B}_{t} \equiv \sqrt{B_{t} \cdot B_{t-1}}, \\
& P_{t} \text { is the GNP deflator, } 1972 \text { base, } \\
& \pi_{t}^{e} \equiv E\left[\log \left(P_{t+1}\right)\right]-\log \left(P_{t}\right) \text { is an anticipated inflation rate, }
\end{aligned}
$$
where $E\left[\log \left(P_{t+1}\right)\right]$ is a forecasted price level based on the price equation that was estimated over a sample starting in 1948 in Barro(1978b, p. 564),

$\mathrm{FED}_{t}-\overline{\mathrm{FED}}_{t}$ is real federal expenditure (nominal spending divided by the GNP deflator) relative to normal, where the latter is based on a distributed lag of current and past actual values, $\log \left(Y_{t} / \bar{Y}_{t}\right)$ is real GNP, 1972 base, relative to its trend value, $\bar{Y}_{t}$. The estimated coefficient of $\pi_{t}^{e}, 1.12$, s.e. $=.22$, supports the one-toone effect of anticipated inflation on nominal debt growth, as discussed above. The positive estimated coefficient, .61 , s.e. $=.16$, on the temporary federal spending variable is also in accord with the discussion above. Finally, the negative estimated coefficient, -1.75 , s.e. $=.17$, on the GNP relative to trend variable reflects the strong countercyclical response of the deficit. The significant excess of this estimated coefficient magnitude above unity corresponds to the "excessive" amount of countercyclical reaction that was highlighted in the earlier discussion. 
The public debt growth rate equation has also been estimated with the coefficient of the $\pi_{t}^{e}$ variable constrained to equal the theoretical value of unity. The results are then

$$
\begin{gathered}
\left.\mathrm{DB}_{t}=\underset{(.007)}{.015}+\pi_{t}^{\mathrm{e}}+\underset{(.15)}{.62\left[\mathrm{P}_{t}\right.}\left(\mathrm{FED}_{t}-\overline{\mathrm{FED}}_{\mathrm{t}}\right) / \overline{\mathrm{B}}_{\mathrm{t}}\right]-\underset{(.16)}{1.77\left(\mathrm{P}_{\mathrm{t}} \overline{\mathrm{FED}}_{\mathrm{t}} / \overline{\mathrm{B}}_{\mathrm{t}}\right) \log \left(\mathrm{Y}_{\mathrm{t}} / \overline{\mathrm{Y}}_{\mathrm{t}}\right),} \\
\mathrm{R}^{2}=.87, \hat{\sigma}=.022, \mathrm{D}-\mathrm{W}=1.7 .
\end{gathered}
$$

The estimated coefficients are similar to those shown in equation (1), but the standard errors are reduced somewhat.

Table 1 reports for annual data from 1948 to 1976 the values of actual debt growth and the estimated values and residuals from equation (2). The basic empirical procedure is to examine the effects of these residuals--interpreted as departures of public debt movements from the normal pattern of association with the right-side variables--on the subsequent behavior of output and the unemployment rate. ${ }^{11}$ Note that the residuals are, by construction, orthogonal to a variable that is closely related to the departure of current real GNP from trend. Therefore, the present procedure precludes the isolation of contemporaneous effects of debt shocks on output and the unemployment rate. ${ }^{12}$ Given the impact of lagged debt shocks, it is possible to examine whether lagged values of actual debt growth--or, equivalently, of the estimated "normal" amounts of debt growth--have any additional explanatory power for output and the unemployment rate.

The estimated equations for the unemployment rate and real GNP for annual data over the 1949-77 sample are 
(3)

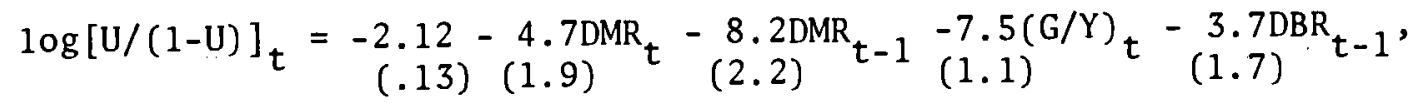

$$
\begin{aligned}
& \mathrm{R}^{2}=.82, \hat{\sigma}=.13, \mathrm{D}-\mathrm{W}=1.9 \text {, }
\end{aligned}
$$

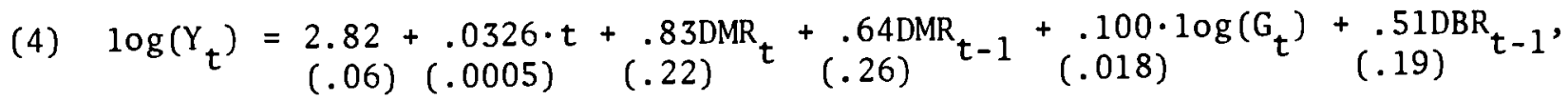

$$
\begin{aligned}
& \mathrm{R}^{2}=.998, \hat{\sigma}=.015, \mathrm{D}-\mathrm{W}=1.5 .
\end{aligned}
$$

The new variables used in equations (3) and (4) are

$\mathrm{U}$ is the unemployment rate in the total labor force, which includes military personnel (table 2),

DMR is the residual from an equation estimated over the 1941-78

period in Barro (1980a, ) for the annual average growth rate

of the M1 definition of the money stock (table 1),

$\mathrm{G}$ is real federal purchases, 1972 base (reported relative to

real GNP in table 2),

DBR is the residual from the public debt growth rate equation (2)

(table 1),

$t$ is a time trend.

The form of the dependent variable in equation (3) corresponds closely to $\log (U)$ over the sample period. Actual values of $U$ and of output growth, DY, are shown along with estimated values and residuals derived from equations (3) and (4) in table 2 .

Equations (3) and (4) indicate significant expansionary effects of contemporaneous and one-year lagged monetary shocks and of the contemporaneous value of government purchases. These effects have been discussed in detail in previous research, as summarized in Barro (1980a, ), and will not be examined here. The new result is the expansionary influence of the one-year-1agged 
debt shock DBR $_{t-1}$. The estimated coefficient of this variable is negative with a t-value of 2.2 in the unemployment rate equation (3) and positive with a $t$-value of 2.7 in the output equation (4)..$^{13}$ Additional lagged values of debt shocks (or monetary shocks) are unimportant; for example, the estimated coefficient of $\mathrm{DBR}_{t-2}$ is -1.8 , s.e. $=1.4$, in an unemployment rate equation; and .04 , s.e. $=.18$, in an output equation.

Lagged values of actual debt growth are insignificant when added to the equations. For example, joint tests that the coefficients of the variables $\left(D B_{t-1}, D B_{t-2}\right)$ are zero in equations that include also up to two lagged values of the DMR and DBR variables yield the test statistics $F_{20}^{2}=1.2,5$ per cent critical value $=3.5$, for the case of the unemployment rate equation, and $\mathrm{F}_{19}^{2}=1.5,5$ per cent critical value $=3.5$, for the output equation. ${ }^{14}$ The estimated coefficients of the variables $\mathrm{DMR}_{t}, \mathrm{DMR}_{t-1}$ and $\mathrm{DBR}_{t-1}$ remain significant when these values of actual debt growth are introduced. These results support the special role of debt shocks, as opposed to the systematic parts of deficit movements, as influences on the unemployment rate and output--however, inferences of this type are sensitive to the identification problems that were mentioned above.

In terms of magnitudes of effect, the estimated unemployment rate and output equations indicate expansionary effects of lagged debt shocks that are significant, but quantitatively less important than those of monetary shocks. ${ }^{15}$ As an illustration of the role of debt shocks, the realized value for DBR of .016 for 1965, which reflects the 1964 tax cuts, is estimated to reduce the unemployment rate for 1966 by about 3-tenths of a percentage point. Correspondingly, the value $\mathrm{DBR}=.008$ for 1964 implies a reduction by about $1-1 / 2$ 
tenths of a percentage point for the 1965 unemployment rate. ${ }^{16}$ The most important explanatory role for the debt shock variable appears for the 1974-75 contraction. In equations that omit the $D B R_{t-1}$ variable, the estimated unemployment rate for 1975 is 7.0 per cent, as compared with an actual value of 8.3 per cent; while the estimated amount of output growth is .008 , as compared with an actual value of -.013 . The inclusion of the lagged debt shock variable implies, given the value $D B R=-.042$ for 1974 , an estimated value for the 1975 unemployment rate of .081 and for output growth of -.014. ${ }^{17}$ Although this effect for 1975 is important, the general pattern of results in the estimated unemployment rate and output equations does not hinge on the inclusion of the 1975-77 observations. For 1949-74 samples, the estimated coefficient of the $D R_{t-1}$ variable in an unemployment rate equation becomes -4.1 , s.e. $=2.5 ;$ and in an output equation, .61, s.e. $=.28$. Although the standard errors are higher than before, these results are in conformity with the estimates shown in equations (3) and (4). (The inclusion of the 1975-77 observations with the earlier values would be accepted by the usual F-test for structural shift.)

The estimated expansionary effects of debt shocks have policy implications that parallel those of monetary shocks. The principal finding is that departures of realized values of debt and money from customary amounts--as determined by a set of explanatory variables--influence real economic activity. The results suggest that the systematic parts of policy as represented by the parameters of a policy rule--for example, by the coefficients in the public debt equations (1) and (2)--do not influence the realizations for debt or money shocks and therefore do not affect the determination of the unemployment 
rate and output in the manner described by equations (3) and (4). The problems in using the present type of empirical results to draw inferences about the economic effects of anticipated movements in money or public debt involve observational equivalence issues (Sargent, 1976a, pp. 1-12; 1976b) and the distinction between unperceived and unanticipated values of shocks (Fischer, 1980). These questions are discussed, but at best on ly partially resolved, in Barro (1980b, section $V$ ). In any event the present results do not prove that a shift in the parameters of deficit policy would leave unchanged the mean values or other moments of the probability distributions for the unemployment rate and output. (In fact, the discussion in the previous section suggested that the choice of parameters in the public debt equation would have some allocative effects.) Tests of these types of propositions require some sample variation in the structure of policy. 
Conclusions on the Behavior of Federal Deficits

The central message from the present discussion is that the systematic parts of federal deficit policy have been reasonable. The major movements in privately-held, interest-bearing federal debt can be explained as aspects of a policy for achieving an intertemporally efficient collection of net revenues in the face of fluctuations in government expenditures, national income and inflation. There is also some indication that the (random) departures of debt changes from the regular pattern have contributed to movements in the unemployment rate and output. However, the fluctuations from this source that have presently been isolated are substantially smaller that those associated with monetary disturbances.

Given these conclusions it is disturbing to see the major "reform" thrust toward a constitutionally-mandated balanced budget at the federal level; see, for example, Buchanan and Wagner (1977, Ch. 12). In effect, this type of proposal is aimed at controlling the size of the federal government by insisting on an intertemporally inefficient method for raising funds. Doubtless, there would be many methods for limiting the scope of government by analogous restrictions of the taxing power to areas that entail the greatest amounts of excess burden per net dollar collected. These policies would be expected to achieve some reduction in the size of the public sector at the expense of increased misallocation per unit of government spending. Such policies seem clearly to be dominated by direct restrictions on the amount of government expenditure, especially in the area of transfers, and by other direct limitations on the scope of governmental powers. Similarly, an objective of controlling inflation and business fluctuations would imply special 
attention to the behavior of money and perhaps also to government purchases, but would devote much less energy to restrictions on the federal deficit. 


\section{References}

Bailey, M.J., National Income and the Price:Level, 2nd ed., New York, McGraw Hil1, 1971。

Barro, R.J., "Are Government Bonds Net Wealth?", Journal of Political Economy, 82, November/December 1974, 1095-1117.

, "Comment from an Unreconstructed Ricardian," Jourial of Monetary Economics, 4, August 1978a, 569-81.

, "Unanticipated Money, Output, and the Price Level in the United States," Journal of Political Economy, 86, August 1978b, 549-80.

, "On the Determination of the Public Debt," Journal of Political Economy, 87, October 1979, 940-71.

, "Unanticipated Money Growth and Economic Activity in the United States," unpublished, University of Rochester; January 1980a.

, "The Equilibrium Approach to Business Cycles," unpublished, University of Rochester, January $1980 \mathrm{~b}$.

Benjamin, D.K. and L.A. Kochin, "A Theory of State and Local Finance: the Comparative Statics of Mobility," unpublished, University of Washington, November 1978.

Brown, E.C., "Fiscal Policy in the "Thirties: a Reappraisal," American Economic Review, 46, December 1956, 857-79.

Buchanan, J.M., Public Principles of Public Debt, Homewood, Ill., Irwin, 1958. 1977. and R.E. Wagner, Democracy in Deficit, New York, Academic Press,

Buiter, W. and J. Tobin, "Debt Neutrality: a Brief Review of Doctrine and Evidence," unpublished, Yale University, September 1978.

Committee for Economic Development, "Taxes and the Budget: a Program for Prosperity in a Free Economy," 1947 (seprinted in A.E.A. Readings in Fiscal Policy, Homewood, I11., Irwin, 1955).

Council of Economic Advisers, Economic Report of the President, Washington D.C., U.S. Government Printing Office, 1962.

Fischer, S., "On Activist Monetary Policy with Rational Expectations," in S. Fischer, ed., Rational Expectations and Economic Policy, Chicago, University of Chicago Press, for the National Bureau of Economic Research, 1980. 
Gordon, R.J., "The Impact of Aggregate Demand on Prices," Brookings Papers on Economic Activity, 3: 1975, 613-62.

Hamburger, M.J. and B. Zwick, "Deficits, Money and Inflation," unpublished, October 1979.

Kydland, F.E. and E.C. Prescott, "A Competitive Theory of Fluctuations and the Feasibility and Desirability of Stabilization Policy," in S. Fischer, ed. Rational Expectations and Economic Policy, Chicago, University of Chicago Press, for the National Bureau of Economic Research, 1980.

Lucas, R.E., "Econometric Testing of the Natural Rate Hypothesis," in O. Eckstein, ed., The Econometrics of Price Determination, Washington, D.C., 1972 .

, "Econometric Policy Evaluation: a Critique," Journal of Monetary Economics, supplement, 1976, 19-46.

Niskanen, W.A., "Deficits, Government Spending, and Inflation: What is the Evidence," Journal of Monetary Economics, 4, August 1978, 591-602.

Okun, A.M. and N. Teeters, "The Full Employment Surplus Revisited," Brookings Papers on Economic Activity, 1: 1970, 77-110.

Pechman, J.A., "Responsiveness of the Federal Individual Income tax to Changes in Income," Brookings Papers on Economic Activity, 2: 1973, $385-421$.

Ricardo, D., Funding System in P. Sraffa, ed, The Works and Correspondence of David Ricardo, V.4. Cambridge, Cambridge University Press, 1951.

Sargent, T.J., Testing for Neutrality and Rationality, Federal Reserve Bank of Minneapolis, June 1976a.

"The Observational Equivalence of Natural and Unnatural Rate Theories of Macroeconomics," Journal of Political Economy, 84, June 1976b, $631-40$. 


\section{Footnotes}

${ }^{1}$ The present value of revenues net of direct collection costs is the magnitude that is actually held fixed. Money creation is not modeled separately, but seems satisfactorily viewed as one form of taxation, which is associated with governmental monopoly power in the issue of high-powered money. It is unclear to me whether current money issue constitutes "current" taxation of money holdings in the same sense that a tax on current labor earnings amounts to a tax on current work; that is, whether elements of the dynamics of inflation have to be considered that differ qualitatively from the dynamics of labor supply. I am also abstracting from chain letter type cases that involve a perpetual deficit finance/no taxation option. These possibilities arise only in paradoxical situations where the present value of private resources is unbounded.

${ }^{2}$ Somewhat different effects arise for changes in interest rates. See n. 4 below.

${ }^{3}$ Although this case is convenient for exposition, the one-to-one link between the expected inflation rate and nominal debt growth does not depend on a one-to-one connection between the expected inflation rate and nominal interest rates.

${ }^{4}$ The finite maturity of existing debt brings in some additional, secondorder effects on debt issue that concern changes in nominal interest rates. See Barro (1979, p. 966) for a discussion. 
${ }^{5}$ The main results use par value data, but only small changes arise when the necessary refinements are made to utilize estimates for the market value of public debt. Recently constructed comprehensive estimates of public debt at market value were made available to me by John Seater.

$6_{\text {The progressivity explanation requires the cross-sectional graduated }}$ nature of the tax system to apply--because of adjustment costs for changing the law--to the behavior of aggregates over the business cycle. The construction of the $\operatorname{tax} 1$ aw to allow the cross-sectional graduations to carry over in this manner to cyclical movements would also require some explanation. In any case this line of argument suggests that a different cyclical behavior of the deficit would apply during the pre-World War I period before the individual income tax was introduced. Thus far, the evidence from that earlier period is not sufficiently precise either to reject or strongly support this viewpoint.

${ }^{7}$ The anticipated inflation rate was measured in two alternative ways. First, a forecast for one-year-ahead inflation (for the GNP deflator) was constructed over the 1948-76 sample from a price equation (Barro, 1978b, p. 564) that was estimated over that period. These values of expected inflation are shown in table 1. Second, a long-term nominal interest rate (Aaa corporate bond rate) was used as a proxy for anticipated inflation. Although this variable was available for the entire 1916-76 period under study, an apparent shift in anticipated real rates of return required the use of a dummy variable for the pre-1941 years. It is also unclear that nominal 


\section{n. 7 continued}

interest rates are closely correlated with anticipated inflation in the preWorld War II period. A direct estimate of the anticipated inflation rate for the pre-1948 years would be a substantial improvement.

${ }^{8}$ My study (1978b) also has the shortcoming of including a nominal interest rate measure as an "explanatory variable" for the price level (through a positive effect on velocity). However, in order for this channel to provide a link between deficits and inflation it would be necessary for the growth rate of public debt to affect the change in interest rates, rather than the level of rates.

${ }^{9}$ Normal real federal spending has been measured as a distributed lag of itself; see the discussion below. Hamburger and Zwick (1979, table 1)

find some evidence for a relation between the deficit and money creation for samples that begin in 1961. However, these equations do not seem to hold fixed the appropriate measure of federal expenditures.

10 This approach would count the portion of the "deficit" that was financed by issue of high-powerd money as a form of current taxation, which may also be appropriate. See n. 1 above.

${ }^{11}$ Since the estimated values are conditioned on current realizations of the right-side variables, these shocks cannot be interpreted as prediction errors. However, the distinction between the type of shock that I am 


\section{n. 11 continued}

presently using and shocks of the "unanticipated" variety is a difficult one to make empirically; see Barro (1980b, section V) for a discussion.

12 The money growth equation that was used to construct monetary shocks includes as a regressor the lagged unemployment rate, but excludes current values of business cycle variables. The estimated coefficient of the contemporaneous monetary shock on output and the unemployment rate (see below) would be biased substantially toward zero if there were an important within-year countercyclical reaction of money growth to unemployment. My asymmetric handling of the debt and money growth variables refelcts a prior view that the countercyclical response of debt would be more important and qicker than that of money. These issues become less important with quarterly data, which I have not yet utilized for the analysis of public debt effects.

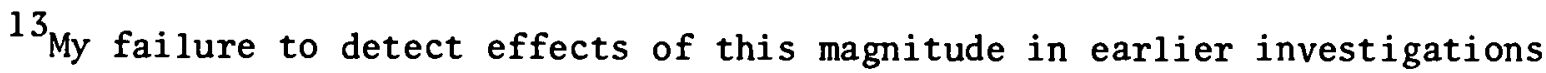
involves the use of 1946 rather than 1949 as a starting date for the samples. With a 1946-77 sample, the estimated coefficient of the $\mathrm{DBR}_{t-1}$ variable in the unemployment rate equation become -0.6 , s.e. $=1.6$; while that in the output equation is 0.29 , s.e. $=0.14$. I suspect that these large changes from the estimates shown in equations (3) and (4) reflect improper measurement of the normal real federal spending variable $\overline{\text { FED }}$ for the immediate postWorld War II years, which would affect the calculations of the DBR and DMR variables. I am presently reconsidering the measurement of the $\overline{\text { FED }}$ variable from the standpoint of the actual time series properties of real federal spending. 
${ }^{14} \mathrm{~A}$ test for the irrelevance of estimated values $\left(\hat{\mathrm{DB}}_{t-1}, \widehat{\mathrm{DB}}_{t-2}\right)$, given the values of the DBR variables, would be equivalent.

${ }^{15}$ This statement refers to equal size values for growth rate residuals, DBR and DMR. The standard-error-of-estimate for the debt growth equation (2) is .022, as compared with a value of .014 for the money growth equation (Barro, 1980a, p. ). That is, the larger size of the typical debt shock partially offsets the smaller coefficient applicable to a given size shock. It may be more appropriate to normalize each shock by multiplication by the level of each stock, $B$ and $M$ respectively, expressed relative to nominal GNP. The values of $D B R$ and DMR were pre-multiplied by one-year lagged values of $B / P Y$ and M/PY, respectively, and regression equations (3) and (4) were rerun. (These changes produced a minor deterioration in the fit of each equation.) The resulting estimated coefficients in the unemployment rate equation were $-16.7 \mathrm{DMR}_{\mathrm{t}}^{*}-30.9 \mathrm{DMR}_{\mathrm{t}-1}^{*}-6.8 \mathrm{DBR}_{\mathrm{t}-1}^{*}$, and in the output equation,
$(7.1)$ $\underset{(0.8)}{2.6 D M R_{t}^{*}}+\underset{(0.9)}{2.1 D M R_{t-1}^{*}}+\underset{(0.5)}{1.3 D B R_{t-1}^{*}}$, where asterisks denote the normalized shocks. Coefficient values above one in the output equation now indicate a form of multiplier response of annual output to infusions of money or debt. Overal1, the results in the normalized forms confirm the impression that monetary shocks have larger unemployment rate and output influences than debt shocks-at least for the effects that have thus far been isolated.

${ }^{16}$ These effects would appear substantially greater if the values of DBR for 1964-65 were contrasted not with zero but with the negative values 
n. 16 continued

that apply for $1960-63$.

${ }^{17}$ On the other hand, the major discrepancies for the 1958 recession are unaffected by the inclusion of the debt shock variable. 
Table 1

Values of Debt Growth, Monetary Growth and Expected Inflation

\begin{tabular}{|c|c|c|c|c|c|c|c|}
\hline & DB & $\widehat{D B}$ & DBR & DM & DM & DMR & $\pi^{\mathbf{e}}$ \\
\hline $\begin{array}{r}1946 \\
7 \\
8 \\
9 \\
1950 \\
1 \\
2 \\
3 \\
4 \\
1955 \\
6 \\
7 \\
8 \\
9 \\
1960 \\
1 \\
2 \\
3 \\
4 \\
1965 \\
6 \\
7 \\
8 \\
9 \\
1970 \\
1 \\
2 \\
3 \\
4 \\
1975 \\
6 \\
7 \\
8\end{array}$ & $\begin{array}{r}-.097 \\
-.030 \\
-.038 \\
.035 \\
-.014 \\
-.018 \\
.019 \\
.019 \\
.013 \\
.000 \\
-.029 \\
-.011 \\
.033 \\
.035 \\
-.014 \\
.022 \\
.018 \\
.006 \\
.008 \\
-.009 \\
-.006 \\
.018 \\
.030 \\
-.025 \\
.036 \\
.076 \\
.057 \\
-.003 \\
.039 \\
.0255 \\
.159 \\
.0114 \\
.092\end{array}$ & $\begin{array}{c}(-.047) \\
(-.064) \\
-.037 \\
-.001 \\
-.021 \\
.009 \\
.033 \\
.040 \\
.017 \\
-.011 \\
-.013 \\
.000 \\
.041 \\
.024 \\
.029 \\
.044 \\
.040 \\
.016 \\
-.001 \\
-.025 \\
-.021 \\
.006 \\
-.009 \\
-.021 \\
.035 \\
.048 \\
.038 \\
-.011 \\
.081 \\
.224 \\
.154\end{array}$ & $\begin{array}{c}(-.050) \\
(.034) \\
-.001 \\
.035 \\
.007 \\
-.027 \\
-.014 \\
-.021 \\
-.004 \\
.011 \\
-.016 \\
-.011 \\
-.009 \\
.011 \\
-.043 \\
-.021 \\
-.021 \\
-.011 \\
.008 \\
.016 \\
.015 \\
.012 \\
.039 \\
-.004 \\
.001 \\
.028 \\
.019 \\
.007 \\
-.042 \\
.032 \\
.006\end{array}$ & $\begin{array}{r}.068 \\
.034 \\
.004 \\
-.010 \\
.026 \\
.044 \\
.049 \\
.024 \\
.015 \\
.031 \\
.012 \\
.005 \\
.012 \\
.037 \\
-.001 \\
.021 \\
.022 \\
.029 \\
.039 \\
.042 \\
.044 \\
.039 \\
.068 \\
.061 \\
.038 \\
.065 \\
.068 \\
.072 \\
.053 \\
.042 \\
.050 \\
.069 \\
.079\end{array}$ & $\begin{array}{l}.055 \\
.028 \\
.008 \\
.003 \\
.006 \\
.032 \\
.039 \\
.041 \\
.019 \\
.027 \\
.024 \\
.020 \\
.018 \\
.033 \\
.035 \\
.028 \\
.038 \\
.034 \\
.037 \\
.039 \\
.043 \\
.041 \\
.040 \\
.044 \\
.045 \\
.045 \\
.059 \\
.062 \\
.059 \\
.059 \\
.061 \\
.060 \\
.065\end{array}$ & $\begin{array}{r}.013 \\
.006 \\
-.003 \\
-.013 \\
.020 \\
.012 \\
.010 \\
-.017 \\
-.003 \\
.004 \\
-.012 \\
-.015 \\
-.006 \\
.004 \\
-.036 \\
-.007 \\
-.017 \\
-.005 \\
.002 \\
.003 \\
.001 \\
-.003 \\
.027 \\
.017 \\
-.007 \\
. .020 \\
.009 \\
.010 \\
-.006 \\
-.018 \\
-.012 \\
.009 \\
.014\end{array}$ & $\begin{array}{r}-.002 \\
-.002 \\
.002 \\
.022 \\
.027 \\
.038 \\
.019 \\
.024 \\
.015 \\
.010 \\
.010 \\
.019 \\
.020 \\
.013 \\
.022 \\
.009 \\
.014 \\
.018 \\
.026 \\
.030 \\
.029 \\
.035 \\
.041 \\
.050 \\
.062 \\
.061 \\
.061 \\
.060 \\
.062\end{array}$ \\
\hline
\end{tabular}

Notes: $B$ is the end-of-year amount of par value, interest-bearing federal debt, exclusive of holdings by the Federal Reserve and federal agencies and trust funds, from Barro (1979, pp. 964-65). $\mathrm{DB}_{t} \equiv \log \left(\mathrm{B}_{t} / \mathrm{B}_{t-1}\right)$. $\triangle \mathrm{DB}$ is the estimated value of the public debt growth rate from equation (2). $D B R \equiv D B-D B$. DM is the estimated value of the annual average growth rate of M1 from Barro (1980a, p. ). DMR $\equiv D M-D M . ~ \pi^{e}$ is the anticipated inflation rate variable used in Barro (1979, pp. 958-59) . Values of DB and DBR for 1946-47 are from Barro (1979, p. 964, cols. 2,3 ). 
Table 2

Values of the Unemployment Rate, Output Growth, and Federal Purchases

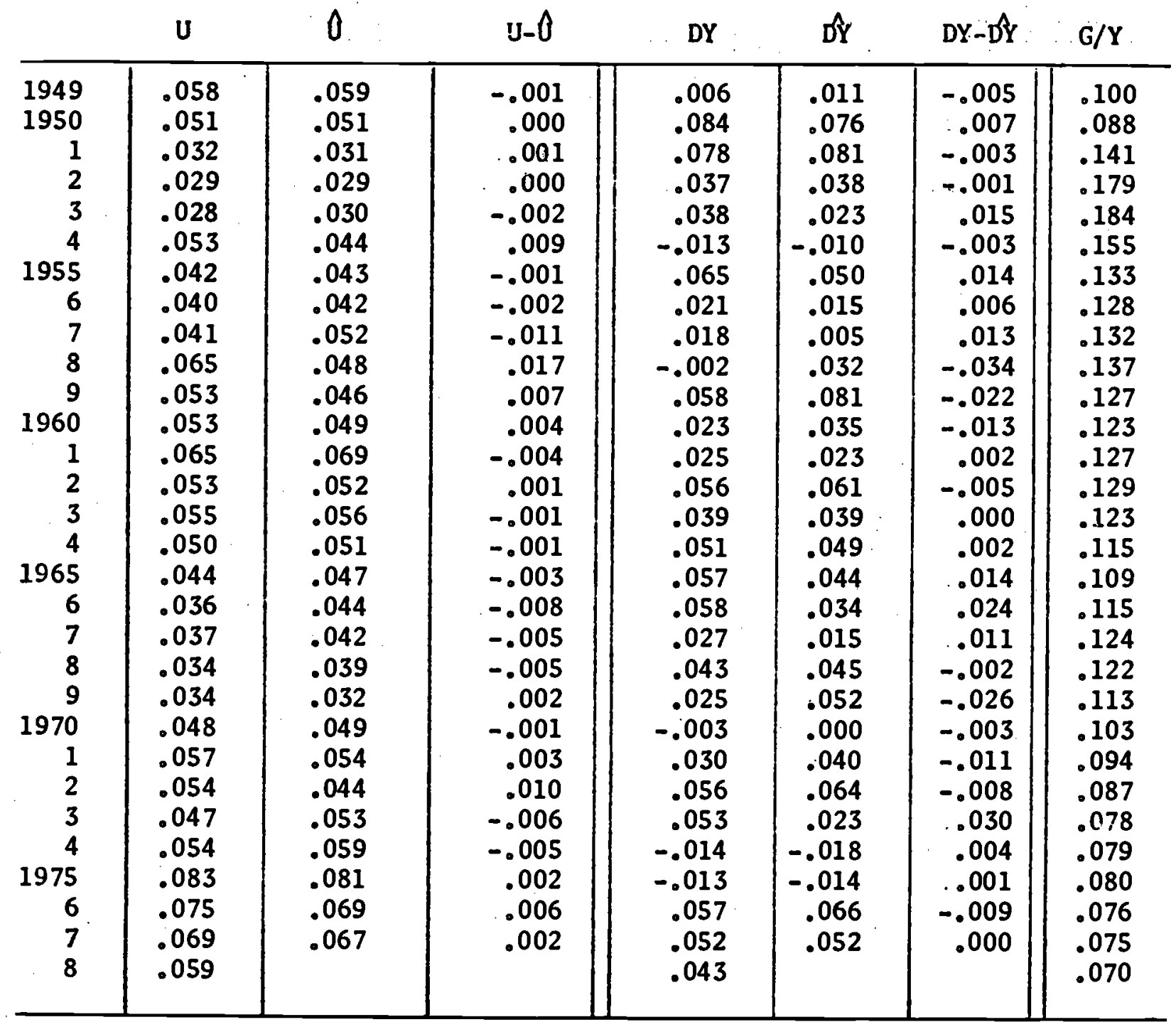

Notes: $U$ is the unemployment rate in the total labor force. $U$ is calculated from equation (3). $Y$ is real GNP, 1972 base. $D Y_{t} \equiv \log \left(Y_{t} / Y_{t-1}\right)$. $\widehat{D Y}_{t} \equiv \log \left(Y_{t}\right)-\log \left(Y_{t-1}\right)$, where $\log \left(Y_{t}\right)$ is from equation $(4) \cdot G$ is real federal purchases, 1972 base. 